\title{
Low prevalence of infection by Sarcocystis neurona in horses from the State of Alagoas, Brazil
}

\author{
Baixa prevalência da infecção por Sarcocystis neurona em cavalos do estado de Alagoas, Brasil \\ Sandra Regina Fonseca de Araújo Valença ${ }^{1}$ (D); Müller Ribeiro-Andrade ${ }^{1}$ (D); Gastón Moré2,3 (D); \\ Pedro Paulo Feitosa de Albuquerque ${ }^{1}$ (D); José Wilton Pinheiro Júnior ${ }^{1}$ (D); Rinaldo Aparecido Mota ${ }^{1 *}$

\begin{abstract}
${ }^{1}$ Laboratório de Doenças Infectocontagiosas dos Animais, Departamento de Medicina Veterinária, Universidade Federal Rural de Pernambuco - UFRPE, Recife, PE, Brasil

${ }^{2}$ Laboratorio de Inmunoparasitología - LAINPA, Facultad de Ciencias Veterinarias - FCV, Universidade Nacional de La Plata UNLP, La Plata, Buenos Aires, Argentina
\end{abstract} \\ ${ }^{3}$ Consejo Nacional de Investigaciones Científicas y Técnicas - CONICET, Buenos Aires, Buenos Aires, Argentina
}

Received June 10, 2018

Accepted April 12, 2019

\begin{abstract}
The aim of this study was to determine the prevalence of infection by Sarcocystis neurona in horses and identify potential risk factors. Were analyzed 427 samples from 36 farms in 21 municipalities in the Alagoas State, Brazil. Presence of anti-S. neurona antibodies was diagnosed by indirect immunofluorescence antibody test (IFAT) and was confirmed using the immunoblot test. Risk factors were assessed through investigative questionnaires on animal management on the farms. The prevalence of anti-S.neurona antibodies was 2.8\% (confidence interval, CI: $1.5-4.9 \%$ ) from IFAT and 1.6\% (CI:0.8-3.34\%) from immunoblot, and there were positive horses on $16.6 \%$ of the studied farms. None of the variables studied presented associations with serological status for $S$. neurona. This is the first report on infection by $S$. neurona in horses reared in Alagoas, Brazil showing a low exposure to $S$. neurona in this region, but with significant numbers of foci.

Keywords: Equine protozoan myeloencephalitis, epidemiology, serology, indirect immunofluorescence, immunoblot.
\end{abstract}

\section{Resumo}

Objetivou-se neste estudo determinar a prevalência e os fatores de risco associados à infecção por Sarcocystis neurona em equinos. Foram analisadas 427 amostras de 36 propriedades localizadas em 21 municípios do estado de Alagoas. O diagnóstico de anticorpos anti-S. neurona foi realizado pela técnica de Imunofluorescência Indireta (IFI) e confirmada por immunoblot. $\mathrm{O}$ estudo dos fatores de risco foi realizado a partir de questionários investigativos sobre o manejo dos animais nas propriedades. A prevalência de anticorpos anti-S. neurona foi de 2,8\% (I.C. 1,5-4,9\%) na IFI e de 1,6\% (I.C. 0,8-3,34\%) no immunoblot com equinos positivos em 16,6\% das propriedades estudadas. Nenhuma variável estudada apresentou associação com o status sorológico para $S$. neurona. Este é o primeiro relato da infecção por $S$. neurona em equinos criados no Estado de Alagoas, Brasil, confirmando que os animais desta regiáo têm baixa exposição a $S$. neurona, mas com significativo número de focos.

Palavras-chave: Mieloencefalite protozoária equina, epidemiologia, sorologia, imunofluorescência indireta, immunoblot.

\section{Introduction}

Sarcocystis neurona is a coccidian parasite from Sarcocystidae family of the phylum Apicomplexa. It definitive hosts are opossums of the species Didelphis virginiana in North America and Didelphis albiventris in South America, and a variety of other mammals could act as intermediate hosts (FENGER et al., 1995; DUBEY et al., 2001, 2015). This coccidian is the main causative

${ }^{*}$ Corresponding author: Rinaldo Aparecido Mota. Departamento de Medicina Veterinária, Universidade Federal Rural de Pernambuco - UFRPE, Rua Dom Manoel de Medeiros, s/n, Dois Irmãos, CEP 52171-900, Recife, PE, Brasil. e-mail: rinaldo.mota@hotmail.com agent of equine protozoan myeloencephalitis (EPM), is widely distributed across the Americas and has a significant economic impact on the horse-rearing industry (MACKAY et al., 2000; DUBEY et al., 2015). The risk factors associated with EPM are related with geographical proximity to areas of definitive host occurrence, age, stress, exercise intensity and seasonal factors (SAVILLE et al., 2000).

Despite the importance of this disease, few studies on infection by $S$. neurona in horses in Brazil have been conducted. Hoane et al. (2006) found $69.6 \%$ of seropositive animals to S. neurona in 
different regions of Brazil, which shows the great exposure of the animals to the protozoan. In particular, little is known about whether animals in the northeastern region of Brazil are exposed to this coccidian.

The state of Alagoas, northeastern Brazil, has 64,126 horses, representing the $22^{\text {nd }}$ equine herd among the States of Brazil (ALAGOAS, 2015). However, there are no studies demonstrating $S$. neurona infection. Therefore, the objectives of the present study were to determine the prevalence of anti-S. neurona antibodies in horses reared in the State of Alagoas, and to identify potential risk factors associated with such infection.

\section{Materials and Methods}

\section{Samples}

A cross-sectional study was conducted on 427 blood serum samples from healthy horses (no MEP signs) of both sexes, aged over 36 months that were kept on 36 farms in rural and urban areas of 21 municipalities in the State of Alagoas, Brazil (Figure 1). Horses of different breeds were sampled from farms that employed semi-intensive or intensive animal farming. Each animal's diet was primarily based on green forage and/or hay as well as balanced ration. The animals were used for work, sport and recreation/leisure activities.

To determine the sample size, the expected prevalence was estimated to be $50 \%$, with a $95 \%$ confidence level and statistical error of $5 \%$. The farms were selected according to the convenience of access and agreement of the farmers with the study.

\section{Indirect Fluorescent Antibody Test (IFAT)}

Initially, the serum samples were screened by IFAT to detect anti-S. neurona IgG antibodies using merozoites of the strain SN37R that were fixed in 12-well plates (12,000-15,000 merozoites/well).
Serum dilutions started at 1:80 (DUARTE et al., 2003) and positive samples underwent serial two-fold dilutions until the endpoint titer was reached. Fluorescein isothiocyanate-labeled goat anti-horse IgG (Sigma-Aldrich', St. Louis, USA) was used as a secondary antibody. Negative and positive control serum samples were included on each slide.

\section{Immunoblot test}

The immunoblot test was performed as previously described by Moré et al. (2014) to confirm the IFAT-positive samples. A concentration of $2 \times 10^{7}$ purified merozoites of the $S$. neurona isolate (strain SN-3) was used as the antigen. Positive serum samples were diluted 1:10 and control reference serum samples (positive and negative) were used on each routine. Anti-horse immunoglobulin G peroxidase conjugate (1:500) was used as the secondary antibody. Reactivity to antigens with relative mobility of $7-10$ and $16 \mathrm{kDa}$ and additionally to the $30 \mathrm{kDa}$ was considered specific for antibodies against $S$. neurona.

\section{Risk factor assessment and statistical analysis}

Risk factors were assessed through application of investigative questionnaires consisting of objective questions about animals' productive and sanitary management, like: history of neurological problems; health status; presence of marsupials (Didelphis spp.) in the farms (frequency seen and access to facilities); origin, types and stocks of feed; horses' water sources; structure and management of the farms. This information served as independent variables for subsequent analyses that evaluated the associations with seropositivity to the protozoa. Univariate analysis was conducted on the variables (chi-square test or Fisher's exact test), followed by multivariate analysis (logistic regression). To perform the frequency and statistical calculations, the EpiInfo software (CDC, version 7) was used.

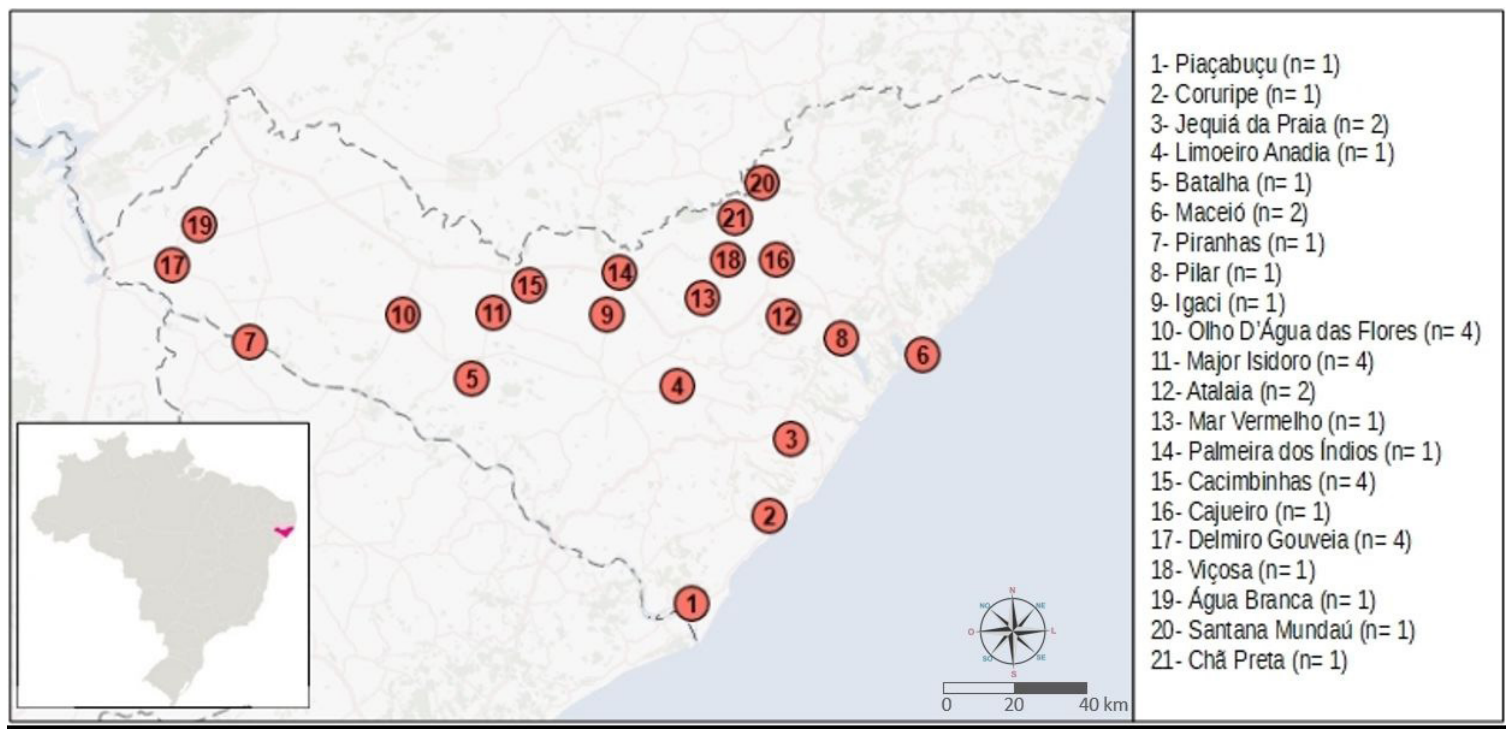

Figure 1. Distribution of the municipalities and the numbers of farms sampled (n) in each of them, in Alagoas State, Brazil. 


\section{Results, Discussion and Conclusion}

The prevalence of antibodies against $S$. neurona was $2.8 \%$ by IFAT (confidence interval, CI: $1.5-4.9 \% ; 12 / 427$ ), with titers of $80(66.7 \% ; 8 / 12), 160(25 \% ; 3 / 12)$ and $320(8.3 \% ; 1 / 12)$. IFAT-positive serum samples were then subjected to the immunoblot test and this confirmed that the prevalence of positive samples with specific antigens against $S$. neurona was 1.6\% (CI: 0.8-3.34\%; 7/427). It was observed that $16.6 \%(6 / 36)$ of the farms presented at least one positive animal. Table 1 shows the frequency of positive animals per property obtained by IFAT and Western blot. Out of the 12 samples that were positive in IFAT, seven were confirmed as immunoreactive to specific antigens against $S$. neurona (Table 2).

The frequency of infection by $S$. neurona in horses in the State of Alagoas was considered low in comparison with previous investigations conducted in Brazil. These included 26.0\% by IFAT in the State of Minas Gerais (RIBEIRO et al., 2016); three studies in Rio Grande do Sul: 33.7\% by ELISA (PIVOTO et al., 2014), 33.8\% by IFAT (ANTONELLO et al., 2015) and 37.7\% by Immunoblot (LINS et al., 2012); and 36\% by Immunoblot in Thoroughbreds horses from Rio de Janeiro, São Paulo and Rio Grande do Sul (DUBEY et al., 1999). In a study on horses from ten different States from Brazil, Hoane et al. (2006) found that $69.6 \%$ of the samples were positive by ELISA. Worldwide, the

Table 1. Frequency of antibodies anti-Sarcocystis neurona in horses per farms from Alagoas State, Brazil.

\begin{tabular}{|c|c|c|c|c|c|}
\hline Farms & Municipies & IFAT positive & $\begin{array}{c}\text { Western blot } \\
\text { positive }^{\mathrm{a}}\end{array}$ & Negative $^{b}$ & Total $^{\text {b }}$ \\
\hline 1 & Água Branca & 1 & - & 12 & 12 \\
\hline 2 & Atalaia & - & - & 34 & 34 \\
\hline 3 & Atalaia & 2 & 1 & 11 & 12 \\
\hline 4 & Batalha & - & - & 22 & 22 \\
\hline 5 & Cacimbinhas & - & - & 8 & 8 \\
\hline 6 & Cacimbinhas & 1 & - & 11 & 11 \\
\hline 7 & Cacimbinhas & 1 & - & 11 & 11 \\
\hline 8 & Cacimbinhas & - & - & 11 & 11 \\
\hline 9 & Cajueiro & - & - & 22 & 22 \\
\hline 10 & Chã Preta & - & - & 9 & 9 \\
\hline 11 & Coruripe & - & - & 6 & 6 \\
\hline 12 & Delmiro Goveia & 1 & 1 & 45 & 46 \\
\hline 13 & Delmiro Goveia & - & - & 6 & 6 \\
\hline 14 & Delmiro Goveia & - & - & 3 & 3 \\
\hline 15 & Delmiro Goveia & - & - & 4 & 4 \\
\hline 16 & Igaci & - & - & 7 & 7 \\
\hline 17 & Jequiá da Praia & - & - & 4 & 4 \\
\hline 18 & Jequiá da Praia & - & - & 4 & 4 \\
\hline 19 & Limoeiro Anadia & - & - & 3 & 3 \\
\hline 20 & Maceió & 3 & 2 & 8 & 10 \\
\hline 21 & Maceió & - & - & 11 & 11 \\
\hline 22 & Major Isidoro & - & - & 11 & 11 \\
\hline 23 & Major Isidoro & 1 & 1 & 10 & 11 \\
\hline 24 & Major Isidoro & - & - & 13 & 13 \\
\hline 25 & Major Isidoro & - & - & 16 & 16 \\
\hline 26 & Mar vermelho & - & - & 11 & 11 \\
\hline 27 & Olho D’águas das Flores & - & - & 7 & 7 \\
\hline 28 & Olho D’águas das Flores & - & - & 6 & 6 \\
\hline 29 & Olho D'águas das Flores & - & - & 8 & 8 \\
\hline 30 & Olho D’águas das Flores & - & - & 16 & 16 \\
\hline 31 & Palmeira dos ìndios & - & - & 16 & 16 \\
\hline 32 & Piaçabuçu & 1 & 1 & 9 & 10 \\
\hline 33 & Pilar & - & - & 25 & 25 \\
\hline 34 & Piranhas & - & - & 5 & 5 \\
\hline 35 & Santana Mundaú & - & - & 11 & 11 \\
\hline 36 & Viçosa & 1 & 1 & 4 & 5 \\
\hline TOTAL & & $12(2.8 \%)$ & $7(1.6 \%)$ & $420(98.4 \%)$ & $427(100 \%)$ \\
\hline
\end{tabular}

${ }^{\mathrm{a}}$ Confirmation of IFAT-positive samples; ${ }^{\mathrm{b} C o n s i d e r i n g ~ t h e ~ r e s u l t s ~ o f ~ t h e ~ c o n f i r m a t i o n ~ f o r ~ i m m u n o b l o t . ~}$ 
Table 2. Titers of the positive samples in IFAT and relationship with the $S$. neurona immunoblot results from horses from Alagoas State, Brazil.

\begin{tabular}{ccc}
\hline Sample ID & IFAT titer & Immunoblot \\
\hline 1 & 80 & Positive \\
2 & 80 & Positive \\
3 & 80 & Positive \\
4 & 80 & Positive \\
5 & 80 & Negative \\
6 & 80 & Negative \\
7 & 80 & Negative \\
8 & 80 & Negative \\
9 & 160 & Positive \\
10 & 160 & Positive \\
11 & 160 & Negative \\
12 & 320 & Positive \\
\hline
\end{tabular}

prevalence of seropositivity for $S$. neurona in horses ranged from $0 \%$ to $89.2 \%$, according to data reviewed by Dubey et al. (2015). Discrepancies in the frequencies have been explained in terms of use of animals of different ages in different states of health, the distribution of definitive hosts and the choice of serological test (HOANE et al., 2006; DUBEY et al., 2015), along with variations in management practices (SAVILLE et al., 2000). In our study, the use of young adult animals without apparent clinical disease that had been reared on farms that followed good management practices must have contributed towards the low seroprevalence detected.

Gennari et al. (2016) investigated the exposure of donkeys from different States of northeastern Brazil (including Alagoas State) to $S$. neurona, demonstrating frequency of infection of $3 \%$ (10/333), using IFAT. Donkeys and horses belong to the genus Equus, differ physiologically and socioeconomically but have similarities in feeding habits. Considering that the ingestion of oocysts is the main route of infection both animals, reinforces the findings of this work that shows the low exposure of the agent in the studied region.

Investigation of antibodies using serological techniques is the main tool for making ante mortem diagnosis of EPM, and this only indicates whether horses have been exposed to $S$. neurona. Serological techniques cannot provide certainty that infection by this protozoan is present, or even whether clinical signs are caused by $S$. neurona (JOHNSON et al., 2013). The combination of factors, such as presence of specific antibodies, typical clinical signs and the complete differential diagnosis, defines EPM diagnosis and the therapeutic actions (DUBEY et al., 2015).

In our study, the choice of cutoff titer in IFAT (1:80) was based on the findings of Duarte et al. (2003), in which choosing this cutoff point resulted in sensitivity of $88.9 \%$ (CI: $51.8-99.7 \%)$ and specificity of 100\% (CI: 91-100\%). Elevation of the cutoff avoids or diminishes the possibility of detecting cross-reactions (false positives), given that because of phylogenetic proximity, species of the genus Sarcocystis may present the same or similar surface proteins (SAVILLE et al., 2004). A serological study developed by Antonello et al. (2015) on 189 samples from mares demonstrated that $64(33.6 \%)$ of the animals were positive for antigens against
S. neurona in IFAT. When these same samples were subjected to IFAT with Sarcocystis cruzi antigen (cattle-canids life cycle), 57 samples were positive, i.e. there were only seven samples that were positive solely for antigens against $S$. neurona. Because of this possibility of cross-reactions, combinations of diagnostic serological tests are recommended (DAFT et al., 2002).

We also used the Immunoblot test, which has been considered as "gold standard" for identification of specific antibodies against S. neurona in horses (DUBEY et al., 2015). This confirmed that seven of the twelve samples that were positive in IFAT were also positive for reactivity to specific antigens against $S$. neurona. Even though we chose a cutoff that maximized the specificity of IFAT, five samples were considered as false positives based in 2 tests results.

The univariate analysis did not detect any variable to productive or sanitary management with infection by $S$. neurona, probably due to the low prevalence of positive animals in the farms. However, Didelphis spp. were frequently observed in the farms, leading to likely contamination with $S$. neurona. According to Fenger et al. (1995), horses are infected through accidental ingestion of sporocysts that were eliminated in the feces of opossums. According to Dubey et al. (2015), the species responsible for this in South America is Didelphis albiventris, which is a definitive competent host. Saville et al. (2000) conducted a seroepidemiological study in the United States and found that poor storage of hay $(\mathrm{OR}=3.1)$, the season of the year (spring, $\mathrm{OR}=3.1$; summer, $\mathrm{OR}=3.2$; or autumn, $\mathrm{OR}=6.0$ ) and previous stressful events such as racing, reproduction or concomitant diseases $(\mathrm{OR}=10.0)$ were factors that could favor infection and emergence of EPM. In Brazil, Ribeiro et al. (2016) found that the risk factors relating to the farm were the presence of forest reserves either within or adjacent to the farm $(\mathrm{OR}=10.5)$ and use of animal feed that the farm itself produced $(\mathrm{OR}=6.73)$.

This is the first report on the presence of antibodies against S. neurona in horses reared in the State of Alagoas, Brazil. Despite low prevalence, seropositive horses were found to be present with a wide distribution.

\section{References}

Alagoas. Pesquisa Pecuária Municipal (PPM) - Efetivos de Equinos [online]. 2015 [cited 2018 Apr 1]. Available from: http://dados.al.gov.br/dataset/ mapas-de-agropecuaria-2014/resource/83d7d333-3559-4512-917aa60e32d6d950

Antonello AM, Pivoto FL, Camillo G, Braunig P, Sangioni LA, Pompermayer E, et al. Investigação de anticorpos contra Sarcocystis neurona e Sarcocystis cruzi em equinos. Arq Bras Med Vet Zootec 2015; 67(5): 1465-1468. http://dx.doi.org/10.1590/1678-4162-7374.

Daft BM, Barr BC, Gardner IA, Read D, Bell W, Peyser KG, et al. Sensitivity and specificity of western blot testing of cerebrospinal fluid and serum for diagnosis of equine protozoal myeloencephalitis in horses with and without neurologic abnormalities. J Am Vet Med Assoc 2002; 221(7): 1007-1013. http://dx.doi.org/10.2460/javma.2002.221.1007. PMid:12369679.

Duarte PC, Daft BM, Conrad PA, Packham AE, Gardner IA. Comparison of a serum indirect fluorescent antibody test with two Western blot tests for the diagnosis of equine protozoal myeloencephalitis. J Vet Diagn Invest 
2003; 15(1): 8-13. http://dx.doi.org/10.1177/104063870301500103. PMid:12580288.

Dubey JP, Howe DK, Furr M, Saville WJ, Marsh AE, Reed SM, et al. An update on Sarcocystis neurona infections in animals and equine protozoal myeloencephalitis (EPM). Vet Parasitol 2015; 209(1-2): 1-42. http:// dx.doi.org/10.1016/j.vetpar.2015.01.026. PMid:25737052.

Dubey JP, Kerber CE, Granstrom DE. Serologic prevalence of Sarcocystis neurona, Toxoplasma gondii and Neospora caninum in horses in Brazil. $J$ Am Vet Med Assoc 1999; 215(7): 970-972. PMid:10511862.

Dubey JP, Lindsay DS, Saville WJ, Reed SM, Granstrom DE, Speer CA. A review of Sarcocystis neurona and equine protozoal myeloencephalitis (EPM). Vet Parasitol 2001; 95(2-4): 89-131. http://dx.doi.org/10.1016/ S0304-4017(00)00384-8. PMid:11223193.

Fenger CK, Granstrom DE, Langemeier JL, Stamper S, Donahue JM, Patterson JS, et al. Identification of opossums (Didelphis virginiana) as the putative definitive host of Sarcocystis neurona. J Parasitol 1995; 81(6): 916-919. http://dx.doi.org/10.2307/3284040. PMid:8544064.

Gennari SM, Pena HFJ, Lindsay DS, Lopes MG, Soares HS, Cabral $\mathrm{AD}$, et al. Prevalence of antibodies against Neospora spp. and Sarcocystis neurona in donkeys from northeastern Brazil. Rev Bras Parasitol Vet 2016; 25(1): 109-111. http://dx.doi.org/10.1590/S1984-29612016003. PMid:26982557.

Hoane JS, Gennari SM, Dubey JP, Ribeiro MG, Borges AS, Yai LE, et al. Prevalence of Sarcocystis neurona and Neospora spp. infection in horses from Brazil based on presence of serum antibodies to parasite surface antigen. Vet Parasitol 2006; 136(2): 155-159. http://dx.doi.org/10.1016/j. vetpar.2005.10.023. PMid:16310955.

Johnson AL, Morrow JK, Sweeney RW. Indirect fluorescent antibody test and surface antigen ELISAs for antemortem diagnosis of equine protozoal myeloencephalitis. J Vet Intern Med 2013; 27(3): 596-599. http://dx.doi.org/10.1111/jvim.12061. PMid:23517480.

Lins LA, Feijó LS, Nogueira CEW. Mieloencefalite protozoária equina nas regiôes da Campanha e do sul do Rio Grande do Sul no período de 1998-2006. Rev Ciênc Agrovet 2012; 11(3): 248-250.

MacKay RJ, Granstrom DE, Saville WJ, Reed SM. Equine protozoal myeloencephalitis. Vet Clin North Am Equine Pract 2000; 16(3): 405-425. http://dx.doi.org/10.1016/S0749-0739(17)30086-X. PMid:11219340.

Moré G, Vissani A, Pardini L, Monina M, Muriel M, Howe D, et al. Seroprevalence of Sarcocystis neurona and its association with neurologic disorders in Argentinean horses. J Equine Vet Sci 2014; 34(9): 1051-1054. http://dx.doi.org/10.1016/j.jevs.2014.06.002.

Pivoto FL, Macêdo AG Jr, Silva MV, Ferreira FB, Silva DA, Pompermayer E, et al. Serological status of mares in parturition and the levels of antibodies ( $\mathrm{IgG}$ ) against protozoan family Sarcocystidae from their precolostral foals. Vet Parasitol 2014; 199(1-2): 107-111. http://dx.doi. org/10.1016/j.vetpar.2013.10.001. PMid:24183649.

Ribeiro MJM, Rosa MHF, Bruhn FRP, Garcia ADM, Rocha CBMD, Guimarães AM. Seroepidemiology of Sarcocystis neurona, Toxoplasma gondii and Neospora spp. among horses in the south of the State of Minas Gerais, Brazil. Rev Bras Parasitol Vet 2016; 25(2): 142-150. http://dx.doi. org/10.1590/S1984-29612016029. PMid:27334814.

Saville WJ, Dubey JP, Oglesbee MJ, Sofaly CD, Marsh AE, Elitsur E, et al. Experimental infection of ponies with Sarcocystis fayeri and differentiation from Sarcocystis neurona infections in horses. J Parasitol 2004; 90(6) 1487-1491. http://dx.doi.org/10.1645/GE-313. PMid:15715250.

Saville WJ, Reed SM, Morley PS, Granstrom DE, Kohn CW, Hinchcliff $\mathrm{KW}$, et al. Analysis of risk factors for the development of equine protozoal myeloencephalitis in horses. J Am Vet Med Assoc 2000; 217(8): 1174-1180. http://dx.doi.org/10.2460/javma.2000.217.1174. PMid:11043688. 